\title{
Assessment of Root Plate Structure in Wind-Thrown Trees of Melia dubia
}

\author{
A. N. Arunkumar* and Shakti Chauhan \\ Institute of Wood Science and Technology, Bengaluru, India
}

Date Received: 2018-03-27

Date Accepted: 2018-04-25

\begin{abstract}
Root plays a significant role in tree growth and development and information pertaining to spread of the root and its depth will be useful for establishing plantations. Most of the root studies are generally carried out in trees growing in urban areas in avenues, but limited studies are carried out in plantations. Being an underground part of the tree, there are inherent difficulties in understanding root architecture. Uprooting of trees due to storm or wind damage provides an ideal opportunity to obtain critical understanding about tree roots. Such study has been carried out in an 11 year old storm ravaged Melia dubia plantation in Punjab, India. Field observations such as tree girth, root girth, root plate width and depth was recorded on uprooted trees. A large variability was recorded for all the traits. Root plate width and depth ranged from 1.42 to $5.17 \mathrm{~m}$ and 0.75 to $2.50 \mathrm{~m}$, respectively. A strong positive relationship between tree girth and primary root girth, root plate width and depth identified in this study provides base line information which can be used while establishing $M$. dubia plantations.
\end{abstract}

Keywords: Melia dubia, root plate, root width, root depth, wind-thrown

\section{Introduction}

Tree roots are essential components which aid in supplying water, minerals, storage of carbohydrate, participate in hormonal signaling and most importantly providing physical anchorage in the soil (Kozlowski and Pallardy, 1997). Therefore it plays a significant role in determining the size of the tree (Thomas, 2000). Studies on tree roots provide basic information to plantation managers about effect of spacing and thinning needed for raising trees. In agro-forestry, it provides an understanding on probable competition arising between tree roots and surface root feeding agricultural crops. However, tree root studies are generally difficult for tropical tree species and most of the studies are restricted to urban forestry (Day, 2011). Unlike agricultural crops, data on tree root studies are scanty because excavating roots is extremely difficult and enormously labour intensive. Therefore root system analysis is not as easy as the above ground system (Smith et al., 2011). Moreover the periodic changes occurring in case of above ground morphological traits are well understood but not completely known in case of root system. Limited studies that have been carried out on tree roots are those when trees are uprooted due to storm or wind damage.

Melia dubia (Syn: M. composita) is an indigenous fast growing multipurpose tree attaining a height of $20 \mathrm{~m}$, having a spreading crown with a cylindrical straight bole of about 9-10 m. In India, it is generally distributed in Bengal, Sikkim, Upper Assam, Orissa, Deccan and Western Ghats (Parthiban et al., 2009). When converted in green state, the logs can be seasoned well. If left unseasoned for long, it tends to develop end splitting and discolouration. The wood has various uses such as packing cases, cigar boxes, ceiling planks, building and construction materials, agricultural implements, pencils, matchboxes, splints, catamarans, musical instruments, tea boxes, and plyboards (Sharma, et al., 2012).

*Correspondence: anarunkumar@gmail.com

ISSN 2235-9370 Print/ISSN 2235-9362 Online @ C University of Sri Jayewardenepura 
Further, the wood is extremely valued in veneer and can also be used for developing wood composites. M. dubia has been used in Indian folklore medicine to control insect pests (Kaul et al., 2002) and the bark extract of the tree has bio-pesticide properties (Koul et al., 2002). It has also been integrated as an ideal tree species in agroforestry programmes (Parthiban et al., 2009).

\section{Material and methods}

A Melia dubia plantation (11-year-old) completely ravaged by a storm in the state of Punjab provided us an opportunity to study its root structure. The plantation was established in 2001-02 at a spacing of 10x10 $\mathrm{m}$ in the Palanpur beat $\left(30.86^{\circ} \mathrm{N} ; 76.70^{\circ} \mathrm{E}\right)$ having soil alluvial type in Siswa Range, Ajitgarh Division, Shiwalik Circle of Punjab. The area experienced a heavy storm on the evening of $15^{\text {th }}$ September 2013 lasting for over 30 minutes with the wind speed exceeding 70-80 km per hour. This left a trail of destruction (Figure 1a). Over 1,258 trees out of 2,400 trees in the plantation were completely uprooted. The study was carried out in December 2013, after ascertaining that there was no interference with this site. Forty five uprooted trees were randomly selected for necessary data collection. Tree girth (m) was measured at the collar region ( $30 \mathrm{~cm}$ above the soil and tree interface) and girth of the tap root $/ \mathrm{main}$ root (referred as root girth) that descends from the trunk (m) was measured just below the root plate by clearing the soil mass adherent to the root. Tree root plate is a stiff, shallow, horizontal disk-shaped rooting area, along with associated soil mass which is under and near the stem base (Coder, 2014) (Figure. 1b). The root plate depth $(\mathrm{m})$ and width $(\mathrm{m})$ was also recorded. Root plate volume $\left(\mathrm{m}^{3}\right)$ was estimated assuming the root plate as a spherical cap using the equation 1. A Pearson's correlation analysis was carried out to analyze the interrelationship between tree girth and root parameters

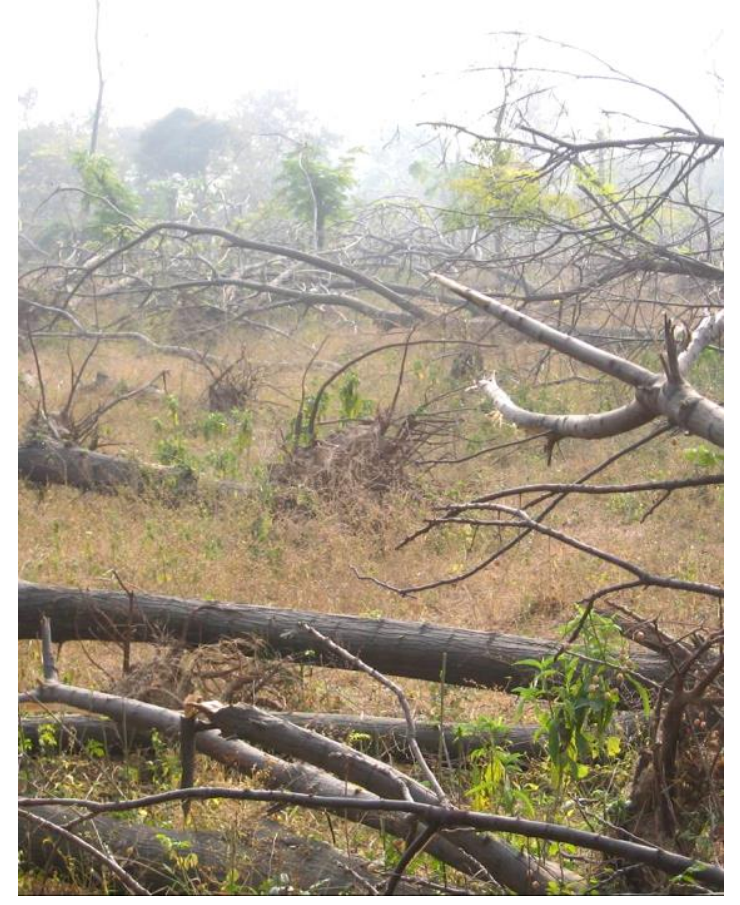

Figure 1a: Wind thrown trees of Melia dubia.

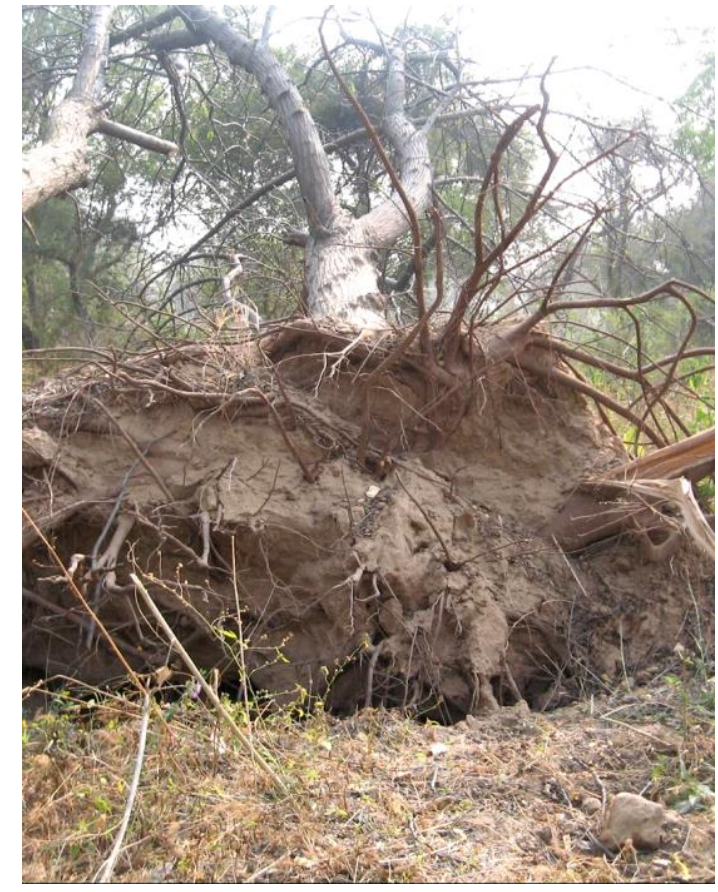

Figure 1b: A typical root plate structure of Melia dubia. 


$$
V=\frac{1}{6} \pi h\left(3 r^{2}+h^{2}\right)
$$

where;

$$
\begin{aligned}
& \mathrm{V}=\text { root plate volume } \\
& \mathrm{h}=\text { root plate depth } \\
& \mathrm{r}=\text { root plate radius }
\end{aligned}
$$

\section{Results and discussion}

A large variability in all the parameters is evident from Table 1 as the coefficient of variation value is more than $25 \%$ for all parameters and the highest being in root girth $(45.08 \%)$. Tree girth ranged from 0.58 to $1.80 \mathrm{~m}$, where as the root girth varied from 0.18 to $1.37 \mathrm{~m}$. Root plate width and depth ranged from 1.42 to $5.17 \mathrm{~m}$ and 0.75 to $2.50 \mathrm{~m}$, respectively. It is interesting to note that tree girth was nearly twice the size of primary root girth. Similarly, root plate width was nearly twice that of root plate depth. The relationship of root plate parameters with tree girth, the single most important above ground morphological trait was also investigated (Table 2).

Table 1: Descriptive statistics for tree girth, root girth, root plate width and depth.

\begin{tabular}{clllll}
\hline S. No. & Parameter & Mean & CV $(\%)$ & Minimum & Maximum \\
\hline 1 & Tree girth $(\mathrm{m})$ & 1.08 & 27.64 & 0.58 & 1.80 \\
2 & Root girth $(\mathrm{m})$ & 0.52 & 45.08 & 0.18 & 1.37 \\
3 & Root plate width $(\mathrm{m})$ & 3.20 & 31.09 & 1.42 & 5.17 \\
4 & Root plate depth $(\mathrm{m})$ & 1.55 & 23.65 & 0.75 & 2.50 \\
5 & Root plate volume $\left(\mathrm{m}^{3}\right)$ & 9.75 & 71.22 & 1.51 & 27.19 \\
\hline
\end{tabular}

Table 2: Correlation matrix between tree girth and root parameters.

\begin{tabular}{lcccc}
\hline & Tree girth & Root girth & Root plate width & Root plate depth \\
\hline Tree girth & 1 & & & \\
Root girth & $0.57^{*}$ & 1 & & \\
Root plate width & $0.71^{*}$ & 0.32 & 1 & 1 \\
Root plate depth & $0.72^{*}$ & $0.48^{*}$ & $0.64^{*}$ & $0.83^{*}$ \\
Root plate volume & $0.77^{*}$ & $0.42^{*}$ & $0.92^{*}$ & \\
\hline
\end{tabular}

$(* \mathrm{p}<0.01)$

Tree girth had a strong positive relationship with primary root girth $(\mathrm{r}=0.57, \mathrm{p}<0.01)$, root plate width $(\mathrm{r}=0.71, \mathrm{P}<0.01)$ and depth $(\mathrm{r}=0.77, \mathrm{p}<0.01)$ and root volume $(\mathrm{r}=0.77, \mathrm{p}<0.01)$. In a study carried out on Alnus incana, the stem diameter at breast height was strongly correlated with root biomass fractions (Bardulius et al., 2015). Trees stand tall and upright with extremely variable wind and soil conditions. The above ground and underground portions in a way seems to be different parts as one is visible and other is hidden, they work in tandem such that biomechanical optimization is at its best (Coder, 2014). Although the main root girth showed significant positive relationship with root plate width and depth, the strength of association was moderate. Root plate width also exhibited a positive association with root depth. Root girth provides an estimation of the root longevity, bending stiffness and the capacity of soil penetration. Several factors play a strong role in tree root formation, development and spread. These include the site, climate, silvicultural practice, biology, soil, geology, hydrology apart from the 
species itself. Generally, root depth in trees varies from one to three meters (Crow, 2005) and in M. dubia it was found that the average root plate depth is $1.55 \mathrm{~m}$. However, it should be emphasised that out of 45 trees, only four trees had a root depth of more than $2 \mathrm{~m}$. Jha (2017) reported that Hybrid Poplar a fast growing tree species when grown in forest system and agroforestry system the root depth was 2.4 and 2.8 $\mathrm{m}$, respectively which is higher than observed in this study. Being a fast growing tree species and grown in fertile alluvium derived soils (sandy to sandy loam) where the soil water availability is in abundance, it is quite likely that roots might have not penetrated deep. Generally it is overstated that tree roots penetrate deeper into the soil. Due to varied sites and species, in case of shallow soils, the root depth is generally underestimated and extensive studies are essential (van Noordwijk et al., 2015).

\section{Conclusion}

The vulnerability of higher girth trees of $M$. dubia to heavy wind or storm should be considered as a caution by the tree growers in the areas prone to such events. Relationship between tree girth and root parameters had not been reported earlier for any plantation grown mature tropical tree species in India. Therefore, further studies on understanding the influence of soil types on fast growing tree species cultivated in different agroclimatic zones is essential before arriving at suitable management practices.

\section{Acknowledgement}

Authors are thankful to the Director, Institute of Wood Science and Technology, Bengaluru, India for his support. We thank the Division Forest Officer and staff of Sahibzada Ajit Singh Nagar Forest Division, Department of Forests and Wildlife Preservation, Punjab for their assistance. We express our gratitude to Professor H. Y. Mohan Ram, INSA Srinivasa Ramanujam Research Professor, for his critical suggestions during the manuscript preparation.

\section{References}

Bardulis, A., Lazdiņa, D., Daugaviete, M., Bardule, A., Daugavietis, U., Rozitis, G., 2015. Above ground and below ground biomass in grey alder Alnus incana (L.) Moench. young stands on agricultural land in central part of Latvia. Agronomy Research. 13: 277-286.

Coder, K. D., 2014. Tree anchorage and root strength. University of Georgia Warnell School of Forestry and Natural Resources monograph publication, pp.67.

Crow, P. 2005. The influence of soils and species on tree root depth. Information Note FCINO78 Forestry Commission Edinburgh.

Day, S., 2011. Tree root ecology in the urban environment and implications for a sustainable rhizosphere. Arboriculture and Urban Forestry. 36: 149-159.

Jha, K.K., 2017. Root structure and belowground biomass of hybrid Poplar in forestry and agroforestry systems in Mediterranean France. Not. Sci. Biol. 9:422-432.

Kaul, O., Multani, J.S., Singh, G., Wahab, S. 2002. Bioefficacy of toosendanin from Melia dubia against gram pod-borer, Helicoverpa armigera (Hubner). Current Science. 83:1387-1391.

Koul, O., Jain, M.P., Sharma, V.K., 2000. Growth inhibitory and antifeedant activity of extracts from Melia dubia to Spodptera litura and Helicoverpa armigera larvae. Indian Journal of Experimental Biology. 38:36-38.

Kozlowski, T, Pallardy, S., 1997. Physiology of Woody Plants. Academic Press, USA.

Parthiban, K.T., Bharathi, A.K., Seenivasan, R., Kamala, K., Rao, M.G.2009. Integrating Melia dubia in agro-forestry farms as an alternate pulpwood species. Asia Pacific Agroforestry Newsletter. 34: 3-4. 
Sharma, S.K., Shukla, S.R., Sujatha, M., Shashikala, S., Kumar, P. 2012. Assessment of certain wood quality parameters of selected genotypes of Melia dubia cav. Grown in a seedling seed orchard. Journal of Indian Academy of Wood Science. 9: 165-169.

Smit, A.L., Bengough, A.G., Engels, C., Van Noordwijk, M., Pellerin, S., Van De Geijn, S.C., 2000. Root Methods: A Handbook. Springer, Berlin.

Thomas, P., 2000. Trees: Their Natural History. Cambridge University Press, UK.

Van Noordwijk, M., Lawson, G., Hairiah, K., Wilson, J., 2015. Root distribution of trees and crops: competition and/or complementarity. In: Ong, C. K., Colin, B. R., Wilson, J., (eds.) Tree-crop interactions: agroforestry in a changing climate. Wallingford, UK, CAB International, 221257. 